\title{
Value Chain of Rice (in Transition to Organic) in Region 02, Philippines
}

\author{
Diosdado C. Cañete ${ }^{1}$
}

\begin{abstract}
The study was focused on Value Chain Analysis (VCA) of rice (in transition to organic) in Region 02. Specifically, it aimed to: a) map out the value chain of rice in transition to organic by identifying the processes, actors and their roles from inputs to product consumption; b) identify and analyze the constrains and issues affecting production and marketing of organic rice; and, c) recommend policy options to improve the production and marketing of rice in transition to organic in Region 02 . The study covered five (5) provinces namely: Batanes, Cagayan, Isabela, Nueva Vizcaya and Quirino. There are six sectors covered by the study along the value chain of organic rice such as Business Development Services (BDS) providers, farm input suppliers, farmer producers, processors, traders/retailers, and consumers.

Organic rice in Region 02 is in infant stage which the different sectors engage in small or minimal volume of operation. There are few registered as organic rice producers in the region. BDS is working effectively their role as provider of support services to other sectors in the value chain of rice. Greater share of value added incurred by processers (millers) and institutional buyers/traders of finish product.

All sectors in different provinces in the region need supports on physical facilities, technological, financial and market linkage from government and non-government organizations to strengthen their operations on production, processing and marketing of organic rice.
\end{abstract}

Index Terms-Value Chain, Value Added, Organic, Sectors and Awareness

\section{RATIONALE}

Organic industry in the Philippines is still considered to be in its infancy or emergent stage, its development and promotion have been spearheaded by the private sector, nongovernment organizations (NGOs) and people's organizations [1]. More recently, efforts to develop the sector have expanded with the active participation of the government and sustained collaboration among stakeholders especially in Cagayan Valley Region [2].

To date, majority of the organic producers supplying the domestic market are community-based, small and medium enterprises spread out in various parts of the country. Exporters to the foreign market include multinationals, medium and large-scale companies based in Mindanao, Negros, Central and Southern Luzon. Enterprises obtain their organic certification from a local certifying body like the Organic Certification Center of the Philippines (OCCP) or international certifiers, which may have tie-ups with locally-basedinspectors [3]. For the Philippines, unofficial estimates placed the export value for organics at US $\$ 10$ million or more in 2003, and at an estimated $20 \%$ annual growth rate, it would have reached US\$18 million or more in 2006. This amount might even triple in 2012. Major export markets are Japan, U.S.A., Canada and Europe [4].

The demand for certified organic products by the foreign and domestic market, and growing health-conscious consumers has encouraged the shift to organic production by conventional farmers. In support to Organic farming, the Philippine National Organic Agricultural Board (PNOAB) was born in 2004, which supports among others: the implementation of the Philippine National Organic Standards and Certification system; and the establishment of a Five-year Organic Industry Development Program for adoption by the respective units of DA in partnership with the private sector [4].

Republic Act (RA) 10068, otherwise known as the Organic Agriculture Act of 2010, was signed into law in April 2010. The IRR of RA 10068 states that initially, 50 million pesos shall be allocated for the first year implementation of the Act and thereafter at least $2 \%$ of the DA's annual budget shall be allocated for organic agriculture program and projects [5]. This will ensure the sustainable development of organic agriculture through the automatic appropriations from the DA's annual budget certain percent for organic farming. The crafting of the IRR for RA 10068 is a clear demonstration of the new DA administration's resolve to cause a shift from conventional farming to organic agriculture [1].

Meanwhile, the study is one of the main research project entitled Value Chain of Analysis of Selected Agricultural Products (in transition to organic) in Region 02, undertaken by the Isabela State University (ISU) and the Department of Agriculture - Bureau of Agricultural Research (DA-BAR). The DA-BAR provided funds, while ISU for manpower and other logistics to facilitate the operation of research. VCA of rice (in transition to organic) in Region 02 is covering five (5) provinces namely: Batanes, Cagayan, Isabela, Nueva Vizcaya and Quirino. There were six sectors covered by the study along the value chain of organic rice such as BDS providers, farm input suppliers, farmer producers, processors, traders/retailers, and consumers.

\section{OBJECTIVES}

The study was focused on value chain analysis of rice (in transition to organic) in Region 02. Specifically, it aimed to: a) mapping out the value chain of rice in transition to organic by identifying the processes, actors and their roles from inputs to product consumption; b) identify and analyze the constrains and issues affecting production and marketing of organic rice; and, c) recommend policy options to improve the production and marketing of rice in transition to organic in Region 02. 


\section{FRAMEWORK OF THE STUDY}

Organic farming is considered as in the embryonic stage today particularly in the Philippines [6]. It is projected by some economies that will be a primordial development in agriculture in the coming decade due to increasing needs of human and as contributory factors for the restoration of our environment. Production and marketing of organic rice is continuously expanding and with an increasing trend not only in the Philippines but also in the international market [7].

In the processes of organic production are affected with external and internal environments. These however, the quality and quantity of internal factors are within the control of the entrepreneurs/farmers which also influenced by the external factors like economic, technological, social/cultural, political/legal, environmental and organic product accreditation conditions surrounded by the producers. Performance of its production depends on the conditions of the internal factors such as manpower, technical, physical facility, farm inputs and capability of producers to sustain the needed funds of the operation [7].

Issues of organic product accreditation would also be considered in this industry to make distinction to ordinary products and that can provide advantages to producers/traders in selling their products in the market. Value adding activities (processing, packaging, storing, distribution and utilization) are made to increase further the potential of increasing income particularly during over supply and low demand of it [8].

At the end of the study, the following were realized: a) map out value chain of organic rice; b) identified marketing system; c) identified constraints and opportunities in production and marketing of organic rice; and $d$ ) implications and recommendations. The conceptual framework of the study is depicted in Fig 1.

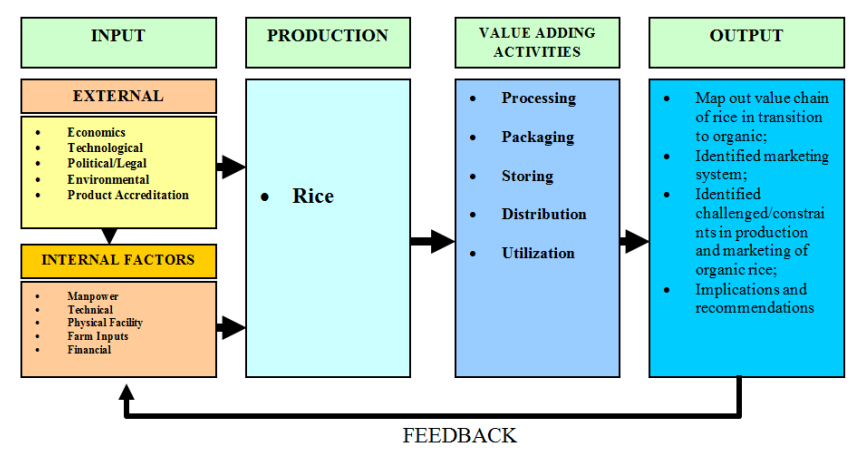

Fig. 1. Framework of the Study

\section{Research Methodology}

The study was conducted from 2014 to 2015, a two-year study of VCA of Organic Rice in Region 02. Information of organic farmers, farm input suppliers, processors and traders of rice were gathered from the DA and other agencies in each province. A total numeration was employed in data gathering to all sectors except for the consumers where stratified sampling was used to calculate the samples of it. Sample consumers were determined based on location and level of income. They must be located in urban centers with household income of Php15,000.00/month and above in the first class municipalities with not less than 20,000 population [9]. The samples in the whole region for each study were calculated using Slovin's formula with 5\% margin of error for consumers [10]. The computed samples were apportioned to provinces and qualified municipalities based on its number of consumers' populations. The samples were drawn at random using Excel random numbers.

The primary data were obtained using semi-structured questionnaire floated to all actors (farm input suppliers, producer, traders, processors, business providers and consumers). Other types of data gathering employed were: Focus Group Discussion (FGD), Problem Analysis, Key Informant Interviews (KII), Environmental Scanning and Strength, Weaknesses, Opportunities and Threats (SWOT) analysis.

Descriptive statistics were used to analyze the gathered data. Cost analysis was employed to trace out the value added in each level in value chain of organic rice from farm inputs utilization up to the consumption of the products. The cost and return analysis was undertaken in each level and conduct a comparative analysis.

\section{Results And Discussion}

\section{A. Demographic Profile of the Respondents}

The distribution of respondents of the study is shown in Fig 2. All respondents except consumers were taken from the reports of the Department of Agriculture - Local Government Units (DA-LGUs) in each province in the region. There were more (667 or $84 \%$ ) number of respondents from consumer sector in the value chain of rice surveyed in the study, then farmer producers (69 or $9 \%$ ), while the traders is the least respondents ( 7 or $1 \%$ ).

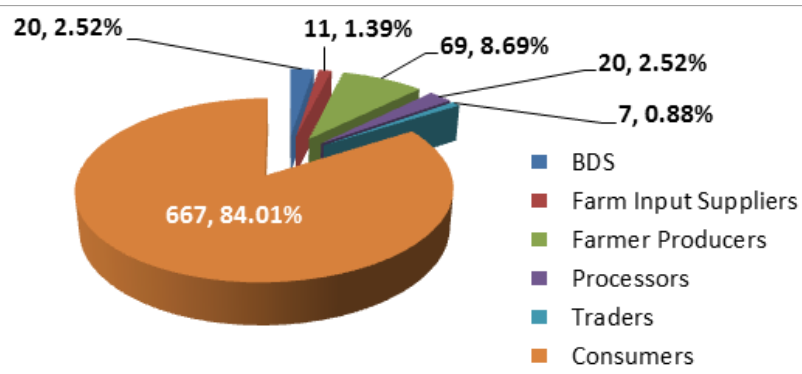

Fig. 2. Proportion of sector respondents of VCA of rice in-transition to organic in Region 02

\section{Business Development Support (BDS) Provider}

BDS providers are an individuals or institutions that provide with support services to the organic farm input producers, rice farmers, processors, and traders which include wholesalers and retailers of organic rice products. There were 20 BDS surveyed distributed throughout in Region 02. More (25\%) numbers of BDS surveyed were located in Cagayan and Nueva Vizcaya provinces, respectively, then from Batanes and Isabela with $15 \%$, respectively. The least (20\%) numbers of BDS were coming from Quirino province as shown in Fig 3.

On BDS had dominantly by males $(60 \%)$ than females $(40 \%)$ which were coming from government institutions 
(90\%) like LGU-DA, Department of Trade and Industry (DTI), Soil and Water Management (SWM), etc., while the rest $(10 \%)$ were non-government institutions such as private company suppliers of products, Magsasaka at Siyentipiko para sa Pag-unlad ng Agrikultura (MASIPAG), Word Vision and others (See Table I).

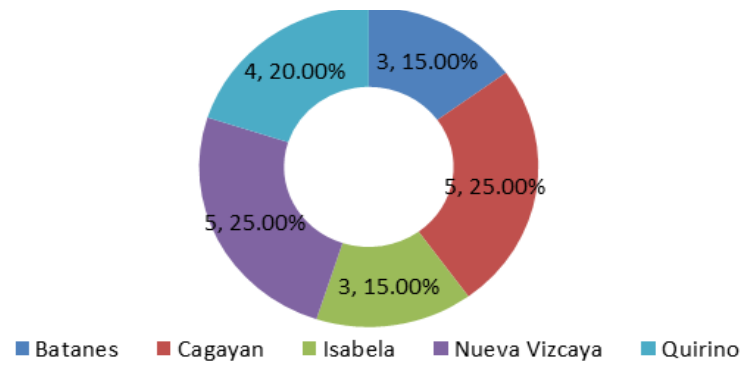

Fig. 3. BDS respondents of rice (in-transition to organic) in Region 02

TABLE I. PROFILE OF BDS RESPONDENTS OF RICE (INTRANSITION TO ORGANIC) IN REGION 02

\begin{tabular}{llcc}
\hline \hline Particular & $\begin{array}{c}\text { Frequency } \\
(\mathrm{n}=20)\end{array}$ & $\begin{array}{c}\text { Percent } \\
(\%)\end{array}$ \\
\hline a. & Gender & & \\
& Male & 12 & 60 \\
& Female & 8 & 40 \\
b. Affiliation to & & \\
& Organization & & \\
& Government & 18 & 90 \\
& Non-government & 2 & 10 \\
\hline \hline
\end{tabular}

The sector of organic rice along the chain which was served most $(85 \%)$ by BDS is producers. Other sectors served were farm inputs traders $(20 \%)$; traders and associations/cooperatives as indicated by $10 \%$ of respondents, respectively. The least were served by them are the processors, extension workers and consumers of organic rice with $5 \%$ of respondents, respectively (See Table II).

TABLE II. SECTORS IN ORGANIC RICE INDUSTRY WHICH THE DBS HAVE PROVIDED SUPPORT SERVICES IN REGION 02

\begin{tabular}{llcc}
\hline \hline Sectors/Actors & $\begin{array}{c}\text { Frequency } \\
(\mathrm{n}=20)\end{array}$ & $\begin{array}{c}\text { Percent } \\
(\%)\end{array}$ \\
\hline 1. & $\begin{array}{l}\text { Farm inputs traders on } \\
\text { organic rice }\end{array}$ & 4 & 20 \\
2. & $\begin{array}{l}\text { Organic rice } \\
\text { producers/growers }\end{array}$ & 17 & 85 \\
3. & Organic rice traders & 2 & 10 \\
4. & Organic rice processors & 1 & 5 \\
5. & Organic rice consumers & 1 & 5 \\
6. & Organic rice & 2 & 10 \\
7. & associations/cooperatives & 1 & 5 \\
\hline \hline
\end{tabular}

\section{Farm Input Suppliers}

Farm input suppliers is the second actor/sector where there existence is equally very important. They linked the producers of rice supplying organic farm inputs like seeds, fertilizers, pesticides, and other farm supplies. Merchant farm input suppliers also provided financing in some extent to assure trading with farmers of their products.

There were eleven farm input retailers surveyed; four (36.36\%) from Isabela, three (27.27\%) from Nueva Vizcaya, two (18.18\%) from Cagayan, and one $(9.09 \%)$ from Quirino and Batanes provinces, respectively (Fig 4). Most of them were males $(81.82 \%)$, an age ranging from 40 to 54 years old with an average age of 47.20 years (See Table III).

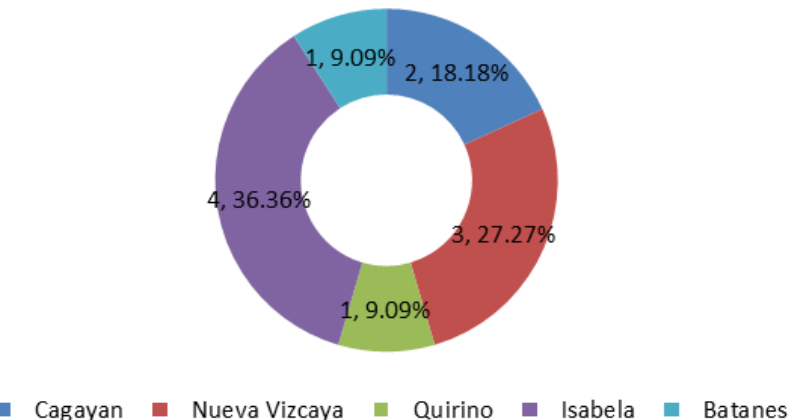

Fig. 4. Farm Input Supplier respondents of rice (intransition to organic) in Region 02

TABLE III. LOCATION AND PROFILE OF FARM INPUT SUPPLIERS IN REGION 02

\begin{tabular}{lcc}
\hline \hline \multicolumn{1}{c}{ Particular } & $\begin{array}{c}\text { Frequency } \\
(\mathrm{n}=11)\end{array}$ & $\begin{array}{c}\text { Percent } \\
(\%)\end{array}$ \\
\hline Gender & & \\
Male & 9 & 81.82 \\
Female & 2 & 18.18 \\
Age (Years) & & \\
40 & 2 & 18.18 \\
44 & 1 & 9.09 \\
46 & 3 & 27.27 \\
50 & 4 & 36.36 \\
54 & 1 & 9.09 \\
Average: 47.20 & & \\
\hline \hline
\end{tabular}

\section{Producers}

Producer of rice in-transition to organic is the heart of the value chain since trading of farm inputs and farm products will terminate and originate from there, respectively. The farmer producers of rice were buyers of farm inputs which they used in farming and the time that they have produce, they sell their products to processors, traders or ultimate consumers of the product.

Fig 5 shows the distribution of 69 farmer producers in Region 02. The province of Nueva Vizcaya has more respondents (23 or $33.33 \%$ ) surveyed, followed by Isabela province (17 or $24.64 \%$ ), Batanes (14 or $20.29 \%$ ), Cagayan (10 or $14.49 \%$ ), and the least from Quirino (5 or $7.25 \%$ ). They were all adults with an age ranging from 47.60 to 53.65 years old and have an average age of 50.87 years. There were more males $(75.90 \%)$ than females $(24.10 \%)$ and all married. Most of them have Roman Catholic religion (73.91\%), then United Methodist Church (UMC) (13.04\%), Born Again Christian (10.14\%), and the least number is Latter Day Saint (2.9\%) (See Table IV). 
TABLE IV. PROFILE OF THE FARMER PRODUCERS OF RICE IN TRANSITION TO ORGANIC IN REGION 02

\begin{tabular}{|c|c|c|}
\hline Particular & $\begin{array}{l}\text { Frequency } \\
(\mathrm{n}=69)\end{array}$ & $\begin{array}{c}\text { Percent } \\
(\%)\end{array}$ \\
\hline \multicolumn{3}{|l|}{ 1. Gender } \\
\hline Male & 63 & 91.30 \\
\hline Female & 6 & 8.70 \\
\hline \multirow{2}{*}{\multicolumn{3}{|c|}{ 4. Religion }} \\
\hline & & \\
\hline Roman Catholic & 51 & 73.91 \\
\hline $\mathrm{UMC}$ & 9 & 13.04 \\
\hline Latter Day Saint & 2 & 2.90 \\
\hline Born Again & 7 & 10.14 \\
\hline \multicolumn{3}{|l|}{ 5. Ethnic Group } \\
\hline Ilocano & 45 & 65.22 \\
\hline Tagalog & 8 & 11.59 \\
\hline Igorot & 5 & 7.25 \\
\hline Ivatan & 11 & 15.94 \\
\hline \multicolumn{3}{|l|}{ 6. Language Spoken } \\
\hline Tagalog & 39 & 32.50 \\
\hline English & 32 & 26.67 \\
\hline Ilocano & 40 & 33.33 \\
\hline Yogad & 1 & 0.83 \\
\hline Ivatan & 8 & 6.67 \\
\hline $\begin{array}{l}\text { 7. Average Number } \\
\text { of Children }\end{array}$ & 4 & \\
\hline $\begin{array}{l}\text { 8. Average } \\
\text { Dependent Children }\end{array}$ & 3 & \\
\hline $\begin{array}{l}\text { Dependent Children } \\
\text { 9. Educational }\end{array}$ & & \\
\hline \multicolumn{3}{|l|}{ Attainment } \\
\hline Elementary & 7 & 10.14 \\
\hline High school & 28 & 40.58 \\
\hline College & 26 & 37.68 \\
\hline Vocational & 3 & 4.35 \\
\hline $\begin{array}{l}\text { College } \\
\text { undergraduate }\end{array}$ & 5 & 7.25 \\
\hline \multicolumn{3}{|l|}{ 10. Tenancy Status } \\
\hline Owner & 58 & 84.06 \\
\hline Amortizing owner & 1 & 1.45 \\
\hline Leaseholder & 5 & 7.25 \\
\hline Shareholder & 4 & 5.80 \\
\hline Caretaker & 1 & 1.45 \\
\hline 11. Years in Farming & 23.13 & \\
\hline $\begin{array}{l}\text { 12. Years in Organic } \\
\text { Rice Farming }\end{array}$ & 7.86 & \\
\hline 13. Sources of Income & & \\
\hline $\begin{array}{l}\text { Average On Farm } \\
\text { Income (Php) }\end{array}$ & $35,549.62$ & \\
\hline $\begin{array}{l}\text { Average Off-farm } \\
\text { Income (Php) }\end{array}$ & $13,600.67$ & \\
\hline $\begin{array}{l}\text { Average Non-farm } \\
\text { Income (Php) }\end{array}$ & $7,953.98$ & \\
\hline
\end{tabular}

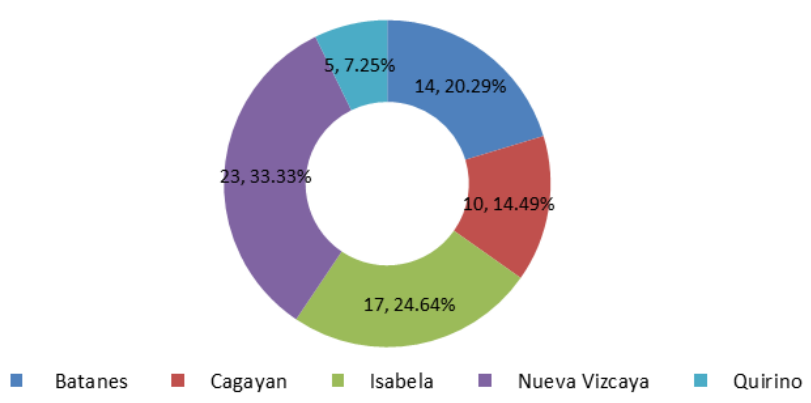

Fig. 5. Farmer producer respondents of rice (intransition to organic) in Region 02

Majority (65.22\%) of farmer producers were belong to Ilocano ethnic group, then Ivatan, Tagalog and Igorot with $15.94 \%, 11.59 \%$, and $7.25 \%$, respectively. They spoke with different languages/dialects which are known to the area in the region. Most of them can speak Ilocano (33.33\%), Tagalog (32.50\%), English (26.67\%), Ivatan (6.67\%) and the least is Yogad $(0.83 \%)$. The farmers had an average of 4 family members and average of 3 dependent children. With respect to their educational attainment, most of them attained with high school levels $(40.58 \%)$, then college levels (37.68\%), elementary levels (10.14\%), college undergraduates $(7.25 \%)$, while the least is vocational course holders $(4.35 \%)$. Almost all farmers $(84.06 \%)$ were owners of their respective farms. Few of them were farm leaseholders $(7.25 \%)$, shareholders $(5.80 \%)$, and amortizing owners and caretakers with $1.45 \%$, respectively. They have longer years in farming with average of 23.13 years, while years in organic rice farming is quite long of about 7.86 years. The farmers have an average on farm, off-farm and non-farm incomes of Php35,549.62, Php13,600.67 and Php7,953.98 per farmer household annually, respectively.

\section{Processors}

Processors are responsible in form utility in marketing of organic rice. They transformed palay to milled rice and from milled rice to finish products. Rice mills are found in different areas in the region operating in commercial scale, while some processors particularly in small (household level) which the farmer itself and their organization have engaged in village level processing. Subsistence farmer processors were engaged hand-pounding to de-hull rice where they have no other means of de-hulling rice particularly in far-flung places in the region. Processors of finish products were also accounted in the study like restaurant, hotels, hospitals, caterers, canteen, etc. offering cooked rice; while some village level producers of delicacies were also monitored in some parts of the region.

The province of Isabela has more numbers of processors of rice interviewed (11 or 55\%), then Cagayan with 4 or $20 \%$, and Nueva Vizcaya, and Quirino provinces with 2 or $10 \%$ in each. The least rice processor interviewed was Batanes with 1 or $5 \%$ (Fig 6). 


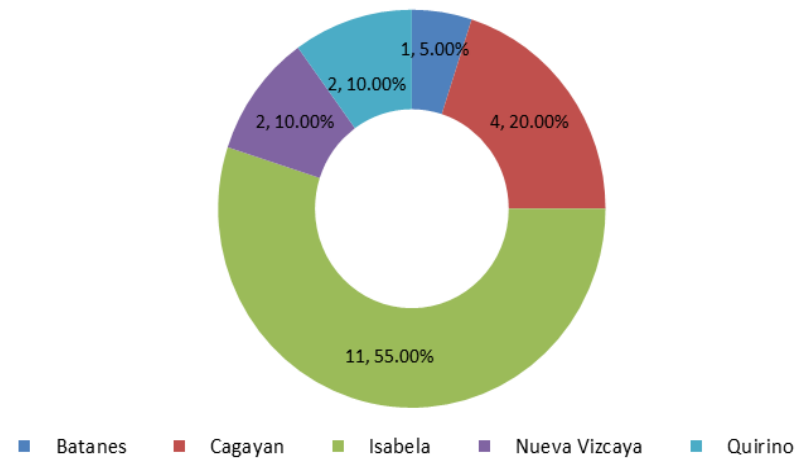

Fig. 6. Product processor respondents of rice (in-transition to organic) in Region 02

Table V shows the profile of delicacies product processors in Region 02. From among the respondents, 95\% of them were females and only 5\% males. This only shows that production of food delicacies is inclined to females. They are sole proprietorship's business producing "kakanin" and selling it in their respective locality as snacks food and gift item.

TABLE V. PROFILE OF DELICACIES PRODUCT PROCESSORS IN REGION 02

\begin{tabular}{lcc}
\hline \hline \multicolumn{1}{c}{ Particular } & $\begin{array}{c}\text { Frequency } \\
(\mathrm{n}=20)\end{array}$ & $\begin{array}{c}\text { Percent } \\
(\%)\end{array}$ \\
\hline Gender & 19 & 95 \\
$\quad$ Female & 1 & 5 \\
$\quad$ Male & & \\
Form of Business & & \\
Organization & & \\
$\quad$ Kakanin Vendor & 20 & 100 \\
\hline \hline
\end{tabular}

Generally, organic rice processors surveyed in the region are small engaging with milling and food processing as their livelihood. Isabela processors have engaged with longer period for almost 12.45 years, then Cagayan and Nueva Vizcaya with 7.5 years, respectively. Batanes processors have 5 years' experience, while Quirino processors have the least ( 3 years) period of processing organic rice as shown in Table VI.

TABLE VI. LENGTH OF TIME OF PROCESSORS HAVE BEEN ENGAGE IN THE PROCESSING OF ORGANIC RICE TO FOOD

\begin{tabular}{lc}
\multicolumn{1}{c}{ ENGAGE IN THE PROCESSING OF ORGANIC RICE TO FOOD } \\
\hline Province & Mean (Years) \\
Cagayes & 5 \\
Isabela & 7.5 \\
Nueva Vizcaya & 12.45 \\
Quirino & 7.5 \\
\hline \hline
\end{tabular}

\section{Traders}

There were more rice traders in Region 02 particularly in the provinces of Cagayan Valley considering the said place is second to Nueva Ecija as rice granary of the Philippines. They vary according to sizes of their operations and sometimes they form rice cartel to control its trading operation in the region. But when it comes to organic rice, the marketing operation is usually mixed with conventional marketing practices of rice in the region. Due to an emerging industry in the area, at this time organic rice marketing and trading is not yet well established unlike to the conventional rice. Most traders surveyed were coming from Isabela and Nueva Vizcaya provinces with $28.57 \%$, respectively; while the rest from Batanes, Cagayan and Quirino provinces with $14.29 \%$, respectively (Fig 7). There were more males $(57.14 \%)$ than females $(42.86 \%)$ with an average age of 49 years old (See Table VII).

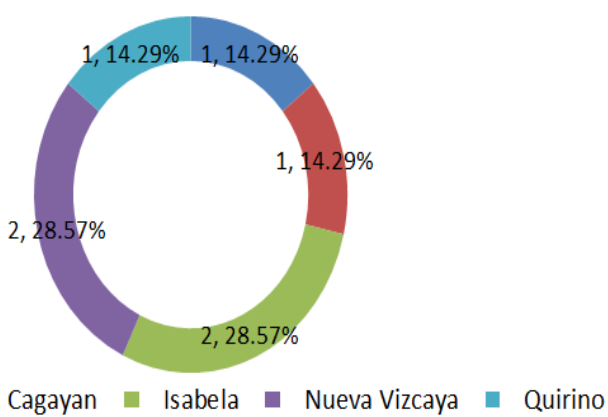

Fig. 7. Trader respondents of rice (in-transition to organic) in Region 02

\section{Consumers}

More consumer respondents were coming from Isabela (280 or $41.98 \%$ ) and Cagayan (264 or $39.58 \%$ ) provinces due to its greater geographic size and more number of urban centers that consumed with the product, while the rests of provinces were few in numbers (Fig 8).

TABLE VII. PROFILE OF ORGANIC RICE TRADERS IN REGION 02

\begin{tabular}{lccc}
\multicolumn{4}{c}{02} \\
\hline \hline Particular & Average & $\begin{array}{c}\text { Frequency } \\
(\mathrm{n}=7)\end{array}$ & $\begin{array}{c}\text { Percent } \\
(\%)\end{array}$ \\
\hline Sex & & & \\
Male & & 3 & 57.14 \\
Female & & & 42.86 \\
Age (average years) & & & \\
Batanes & 44 & & \\
Cagayan & 52 & & \\
Isabela & 43 & & \\
Nueva & 57 & & \\
Vizcaya & 49 & & \\
Quirino & &
\end{tabular}

From 667 respondents, $52 \%$ and $48 \%$ were males and females, respectively. Single respondents have more (76\%) in numbers than married individuals $(15 \%)$ and other marital statuses like separated couples $(8 \%)$ and widows (1\%). Majority (74\%) of them were Roman Catholic religion. Most of them were Ilocano (63\%) but speaking with three languages such as; Ilocano (44\%), Tagalog (31\%) and English (16\%). They were coming from different ethnic groups within and outside the region. From among married respondents, they have an average of 3 children, with average dependent and independent children of 2 , respectively. Regarding to their educational attainment, most of them were high school graduates $(39 \%)$, college graduates $(30 \%)$, and elementary graduates $(16 \%)$. Farming was majority (44\%) occupation of respondents as sources of 
household income, then trading/vending (24\%), and employment to private and public institutions (19\%). Nueva Vizcaya respondents had highest average household income of Php8,909.09, followed by Cagayan (Php8,726.52), Batanes (Php8,567.00), Quirino (Php7,563.38) and Isabela (Php6,792.860) was the least. The mean household income of respondents is Php8,112.00 as reflected in Table VIII.

TABLE VIII. PROFILE INFORMATION OF THE RESPONDENTS

\begin{tabular}{|c|c|c|}
\hline Particular & $\begin{array}{c}\text { Region } 02 \\
(\mathrm{n}=667)\end{array}$ & $\begin{array}{c}\text { Percent } \\
(\%)\end{array}$ \\
\hline \multicolumn{3}{|l|}{$\begin{array}{ll}\text { a. } & \text { Gender }\end{array}$} \\
\hline Male & 347 & 52 \\
\hline Female & 320 & 48 \\
\hline \multicolumn{3}{|l|}{ b. Civil Status } \\
\hline Single & 620 & 76 \\
\hline Married & 125 & 15 \\
\hline Separate & 63 & 8 \\
\hline Widow & 6 & 1 \\
\hline \multicolumn{3}{|l|}{ c. Religion } \\
\hline Roman Catholic & 518 & 74 \\
\hline $\begin{array}{l}\text { Iglesia ni Cristo } \\
\text { (INC) }\end{array}$ & 49 & 7 \\
\hline $\begin{array}{l}\text { United Methodist } \\
\text { (UM) }\end{array}$ & 64 & 9 \\
\hline $\begin{array}{l}\text { Seventh Day } \\
\text { Adventists (SDA) }\end{array}$ & 1 & 0 \\
\hline Others & 65 & 9 \\
\hline \multicolumn{3}{|l|}{ d. Ethnic Group } \\
\hline Ilocano & 433 & 63 \\
\hline Tagalog & 87 & 13 \\
\hline Igorot & 38 & 6 \\
\hline Yogad & 18 & 3 \\
\hline Ivatan & 31 & 4 \\
\hline Cagayano & 82 & 12 \\
\hline \multicolumn{3}{|l|}{ e. Language Spoken } \\
\hline Tagalog & 333 & 31 \\
\hline English & 173 & 16 \\
\hline Ilocano & 471 & 44 \\
\hline Yogad & 11 & 1 \\
\hline Ivatan & 27 & 3 \\
\hline Ifugao & 47 & 4 \\
\hline f. No. of Children & 3 & \\
\hline $\begin{array}{l}\text { g. Dependent } \\
\text { Children }\end{array}$ & 2 & \\
\hline $\begin{array}{l}\text { h. Independent } \\
\text { Children }\end{array}$ & 2 & \\
\hline \multicolumn{3}{|c|}{ i. Educational Attainment } \\
\hline Elementary Grad & 107 & 16 \\
\hline High School Grad & 262 & 39 \\
\hline College Grad & 202 & 30 \\
\hline Others & 96 & 14 \\
\hline \multicolumn{3}{|l|}{ j. Sources of Income } \\
\hline Farming & 318 & 44 \\
\hline Employment & 141 & 19 \\
\hline Trading/Vending & 173 & 24 \\
\hline Others & 98 & 13 \\
\hline $\begin{array}{l}\text { k. Household } \\
\text { monthly Income }\end{array}$ & $8,112.00$ & \\
\hline
\end{tabular}

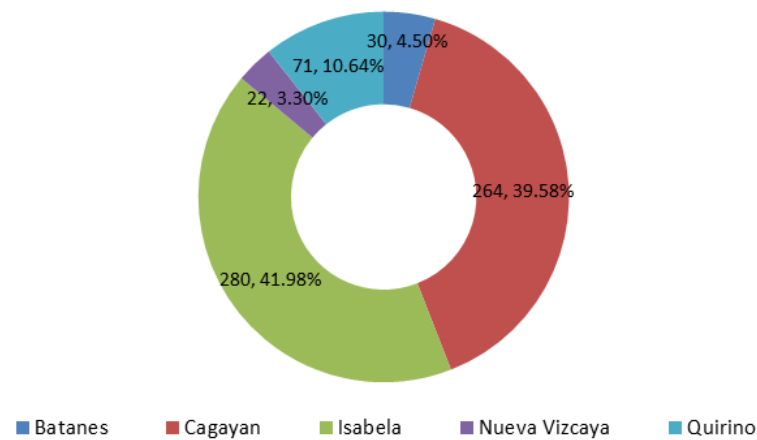

Fig. 8. Consumer respondents of rice (in-transition to organic) in Region 02

\section{B. Mapping Out the Value Chain of Rice in Transition to Organic in Region 02 \\ Region 02 Value Chain Mapping of Rice in Transition to Organic}

From the gathered data through FGD, KII, and survey, although they are not quite big and organized still they resembled the value chain map as shown in Fig 9. There is complete functions performed in the chain by the different actors and sometimes they performed with multiple functions in the chain as also indicated by [11] in their study. In the case of farmers, they are also the producers of inputs and suppliers on it to the market or to co-farmers. Farmers also process their own produce and marketed to traders in the market or their neighborhood.

In the chain, input suppliers were providers of farm inputs to the farmers like rice seeds, organic fertilizers, and other farm supplies in support to production. For some farm inputs that are not available in the market at present like botanical chemicals for biospray, the farmers produced it and used it right away. Few of them were marketed or given as free to co-farmers for the excess produced product. The farmers as producers of organic rice have dispersed two kinds of products after production such raw palay or milled rice. As usual the farmer's practice, palay produced was sold them out after harvesting to assemblers like buying stations or an individual who did canvassing of the product in the locality and to processors like rice millers, institutional, and household particularly in bulk quantity produce. However, some farmers have capability to dry, store, mill their palay and sell it as milled rice to traders and ultimate consumers as also stressed by [7] in their study. In this way, the farmers can get greater margin of profit but it needs greater capital and it has a longer period of time to realize the said amount. Thus, most farmers cannot engage on it since their farming capital were borrowed from the merchant traders and they obliged to sell their produced to them and make their payment right away or else the debt will incur with greater interest that may exceed at $35 \%$ per cropping.

Assemblers in the chain are buyers of palay waiting in their buying stations or they did canvassing of palay to buy from the farmers. They sometimes buy standing crop and they are responsible for the harvest on it. Some assemblers are agents of the big processors (rice millers) in the Cagayan Valley. They borrowed capital, hauling equipment and supplies from their financiers. Once they accumulate the products right away, they deliver it to the warehouse of rice millers where they engaged in. Assemblers get income from 
the margin of profit from sales of the product which also emphasized by [12] in their study.

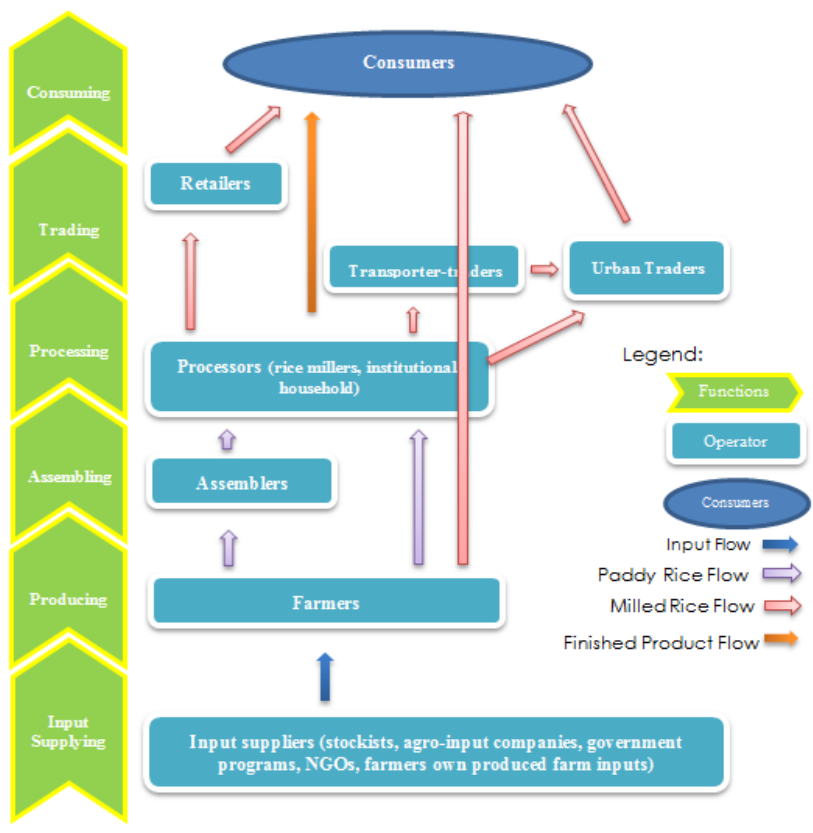

Fig. 9. Value Chain of Organic Rice in Region 02

On the processors that include rice millers, institutional, and households carried milled rice and finish food products. In region 02 , as rice granary of the country has presence of various sizes of rice millers found in different provinces in the region. Big rice millers have their own hauling and storage facilities that make them competitive advantage in marketing rice. They transport milled rice from the region to other regions particularly greater Metro Manila area. In organic rice, operations of processors were limited to the provinces that they milled rice, package and sell it to retailers, urban traders and to ultimate consumers. On institutional processors they are also called institutional consumers that buy organic milled rice as input to produce their products like restaurant, hotels, hospitals, caterers, etc. producing cooked rice and sell it to customers.

Organic rice trading with wholesalers and retailers found in urban and rural areas. In Region 02 particularly in Cagayan Valley, wholesaler traders engaged bulk acquisition of organic milled rice from the millers and transported to other regions especially in greater Metro Manila Areas where there is high demand of the product. Retailer's outlets were very obvious in all provinces in the region particularly that this is promoted by the government. Actually many of the field offices of the DA have their own agribusiness center as retail outlet of well packed organic rice product. Other agencies in provincial, CDA, LGUs, NGOs like MASIPAG [13], Pangkaunlaran Development Association, Inc. (PDAI) 1 and 2 a World Vision assisted groups in Isabela, Pamilya Sagrada in Cagayan, etc. have these also in support to organic promotion in the country as spearheaded by the DA. Furthermore, greater volume of organic rice were available for sale found in the supermarkets like Savemore, Robinson Place at Santiago City, SM City at Cauayan, Pure Gold all over Cagayan Valley, etc.

\section{Value Chain and Cost Mapping of Organic Rice in the Province of Batanes}

The value chain of the organic rice in Batanes is shown in Table IXA and Appendix 1. Value chain mapping is indicating the business service providers, value chain actors and key stakeholders. DA, LGU, and DTI have played an important role in pursuing the activities of different actors in the value chain such as input suppliers, farmer producers, processors and traders. In value added map of rice, farmer producers obtained with Php22.46 (16.04\%) value added to the cost of farm inputs purchased from input suppliers, Php55.00 (39.29\%) per kg added by the processors from its cost of goods, Php15.00 (10.71\%) added by traders from its cost of goods, and Php40.00 (28.57\%) per kg added by the institutional product processors to the cost of goods. The final price of the organic rice is Php140.00 per kg.

\section{Value Chain and Cost Mapping of Organic Rice in the Province of Isabela}

The different actors in the value chain in organic rice have played their roles in the chain like farm inputs suppliers provide farm inputs such as: rice seeds, organic fertilizers, technology in making organic pesticides, etc. needed by the farmers (Table IXA and Appendix 2 and 3). The farmer producers of organic rice are going to provide their produce to the processors/millers, processors/millers then gives their milled rice products to the traders, while traders will supply their products to institutional users and to household consumers. Transient consumers are then supplied by the institutional rice food providers like restaurants, canteens, hotels, hospitals and fast food chains.

Analysis of value added in each actor in the chain is shown in figure below. Farm input suppliers were added Php18.53 or $17.75 \%$ for lowland, while Php17.41 or $16.21 \%$ for upland to the cost of organic rice in the farmer's level. Farmers added with Php37.00 which comprises to $35.44 \%$ to the cost for upland organic rice while, $34.45 \%$ added cost for lowland in processors/millers level. The processors/millers have contributed with Php10.00 which is $9.58 \%$ and $9.31 \%$ in upland and lowland respectively of organic sources of rice at the traders. The institutional consumers have constituted with the highest value added with Php37.40 which contributed to $34.82 \%$ in lowland and $34.82 \%$ for upland to the total cost structure of organic rice per kilo. The ultimate consumer's price now is Php107.40 for a kilo of organic rice.

\section{Value Chain and Cost Mapping of Organic Rice in the Province of Cagayan}

It was found out that the Cagayan province has a strong interrelationship of the different actors in the organic rice value chain due to strong influence of the DA especially because this province is located in the seat of regional administration. There were strong supports of business service providers to different actors in the value chain in the industry. They provided directly the needs of each actor in the value chain. It indicates the different actors from input suppliers to traders were sustained the operation of organic rice in the said province.

On value added map of costs starting from input suppliers, producers, processors, traders, institutional consumers to ultimate consumers have attained a total value of Php108.00 
per kg of rice or Php9.00 per cup of cooked rice in upland organic rice. Of this cost structure, suppliers of farm inputs contributed with $\mathrm{Php} 19.75$ or $18.29 \%$, producers like farmers were able to contribute of Php26.00 or $24.07 \%$, processors with Php15.00 or $13.89 \%$ and traders have contributed with Php43.00 or $39.81 \%$ in the total cost structure of organic rice in the market niche. On the other hand, lowland organic rice has the same final cost (Php108.00/kg) with upland organic rice but with different cost allocations of actors involve in the value chain. There was Php20.92 or $19.37 \%$ contributed by the suppliers of farm inputs, Php26.00 or $24.07 \%$ added by producers, Php 15.00 or $13.89 \%$ added by processors and Php43.00 or $39.81 \%$ added by traders to the total product cost (Table IXA and Appendices 4 and 5).

\section{Value Chain and Cost Mapping of Organic Rice in the Province of Quirino}

To put credit to the DA, academe, other government agencies, Peoples Organization (PO's) and Non-government Organization (NGO's) who exerted their efforts in promoting organic farming particularly in rice production that made farmers and consumers aware of the benefits of the products. There were various business service providers from government and NGOs which made their supports to rice organic industry actors along the value chain in the province of Quirino.

On costs value adding analysis, the finish organic rice product has reached to Php120.00 per kilo or Php10.00 per cup as final price available to the ultimate consumers. In this cost structure, farm input suppliers accounted with Php5.50 (4.58\%) per kilo contribution and Php24.50 (20.41\%), Php30.00 (25\%), Php35.00 (29.17\%) and Php25.00 $(20.83 \%)$ contributed by the farmers, product processors, traders and institutional consumers like restaurant, fast food chain, etc., respectively. In this case, traders have the highest cost $(29.17 \%)$ contribution to the ultimate price of organic rice in the market (Table IXB and Appendix 6).

\section{Value Chain and Cost Mapping of Organic Rice in the Province of Nueva Vizcaya}

In the province of Nueva Vizcaya, value chain of organic has interrelationships of the different actors starting from the supplier of farm inputs up to the traders of the products. Each actor is supported by different business service providers coming from public and private agencies in the province. They provided directly the needs of respective actor in organic rice chain. It was observed that the actor performing multiple functions in the chain e.g. farmers as producers perform the function of input supplier since they produce their own and supply the excess produce to cofarmers or even marketed. In like manner, farmers have go into forward integration through processing their produce palay to milled rice and pack for market. The actors in the chain, business development service providers and the identified persons/organization in the chain.

There were two value adding assessment made from the organic rice products in the province due to price/cost variation incurred by each actor; one for the organic white rice variety and the other one is red rice variety. Organic white rice variety has cheaper cost value in the whole chain as compared to organic red rice variety. The organic white rice variety has a total value added accumulation from input supplier to final consumers of Php96.00, while on the red rice variety has a total accumulated value added cost of Php108.00. The cost deferential is attributed to demand of the product. Institutional consumers like restaurants, canteens, caterers and the like have possessed with the highest percentage (Php46.00 or $47.92 \%$ ) added to the total cost chain of organic white rice variety, while other actors like farmers contributed with Php20.18 or $21.02 \%$, processors with Php18.00 or $18.42 \%$ and traders with Php 10.00 or $10.42 \%$. There is the same pattern of actors in organic red rice variety where the institutional consumers contributed with the highest cost of Php48.00 or $44.44 \%$ from the total cost structure in the chain. The farmers, processors, and traders contributed with Php21.18 or $19.61 \%$, Php20.00 or $18.52 \%$ and Php17.00 or $15.74 \%$, respectively (Table IXB and Appendices 7 and 8).

\section{Challenges/Constraints}

\section{Farm Input Suppliers:}

The farm input suppliers had encountered with the following constraints that affect to their operation: a) lack of substrates/ materials and manpower that resulted to shortage of supply, b) contaminated farm residues as substrates in producing organic fertilizers and pesticides, c) insufficient knowledge in producing organic farm inputs like organic fertilizers and botanical pesticides, d) lack of infrastructures, equipment, transportation facilities that can help facilitate the production and distribution of farm inputs, e) competition of products among farm inputs suppliers, f) insufficient financial capital and technology disseminations to prospective organic farm input suppliers, g) high cost equipment that can be used for production of organic fertilizer and other farm input products which the small producers can't afford, h) insufficient support of R\&D in production and utilization of organic farm inputs especially its efficacy to plant growth and control of pests, i) too rigid requirement of product evaluation and high cost of accreditation/certification as organic farm input producer imposed by the accrediting body, and j) organic farm inputs producers are not fully aware to RA \# 10068 or Organic Agriculture Law.

TABLE IXA. VALUE ADDED CONTRIBUTED BY THE DIFFERENT ACTORS/SECTORS ALONG THE VALUE CHAIN OF RICE IN REGION 02.

\begin{tabular}{lrrr}
\hline \hline \multirow{2}{*}{ Particular } & Batanes & \multicolumn{2}{c}{ Isabela } \\
\cline { 2 - 4 } Farm Input Suppliers & Upland & Lowland & Upland \\
\hline \multirow{2}{*}{ Producers } & 7.54 & 4.47 & 5.59 \\
& $5.39 \%$ & $6.16 \%$ & $5.20 \%$ \\
Processors & 22.46 & 18.53 & 17.41 \\
& $16.04 \%$ & $17.25 \%$ & $16.21 \%$ \\
Traders & 55.00 & 37.00 & 37.00 \\
& $39.29 \%$ & $34.45 \%$ & $34.45 \%$ \\
Institutional Consumers & 15.00 & 10.00 & 10.00 \\
& $10.71 \%$ & $9.31 \%$ & $9.31 \%$ \\
Final Price (Php/kg) & 40.00 & 37.40 & 37.40 \\
& $28.57 \%$ & $34.82 \%$ & $34.82 \%$ \\
\hline \hline
\end{tabular}


TABLE IXB. VALUE ADDED CONTRIBUTED BY THE DIFFERENT ACTORS/SECTORS ALONG THE VALUE CHAIN OF RICE IN REGION 02.

\begin{tabular}{lrrrrr}
\hline \hline \multirow{2}{*}{ Particular } & \multicolumn{2}{c}{ Cagayan } & Quirino & \multicolumn{2}{c}{ Nueva Vizcaya } \\
\cline { 2 - 6 } & Lowland & Upland & Upland & White & Red \\
\hline Farm Input & 3.08 & 4.25 & 5.50 & 1.82 & 1.82 \\
Suppliers & $2.85 \%$ & $3.93 \%$ & $4.58 \%$ & $1.89 \%$ & $1.68 \%$ \\
Producers & 20.92 & 19.75 & 24.50 & 20.18 & 21.18 \\
& $19.37 \%$ & $18.29 \%$ & $20.41 \%$ & $21.02 \%$ & $19.61 \%$ \\
Processors & 26.00 & 26.00 & 30.00 & 18.00 & 20.00 \\
& $24.07 \%$ & $24.07 \%$ & $25.00 \%$ & $18.75 \%$ & $18.52 \%$ \\
Traders & 15.00 & 15.00 & 35.00 & 10.00 & 17.00 \\
& $13.89 \%$ & $13.89 \%$ & $29.17 \%$ & $10.42 \%$ & $15.74 \%$ \\
Institutional & 43.00 & 43.00 & 25.00 & 46.00 & 48.00 \\
Consumers & $39.81 \%$ & $39.81 \%$ & $20.83 \%$ & $47.92 \%$ & $44.44 \%$ \\
Final Price & 108.00 & 108.00 & 120.00 & 96.00 & 108.00 \\
(Php) & & & & & \\
\hline \hline
\end{tabular}

\section{Farmer Producers:}

Farmer producers had encountered the following constrains or problems in production of organic products in the region. These includes: a) insufficient organic farm inputs available in the locality like seeds, fertilizers and for control of insect pest and diseases in rice, b) organic rice farming is too laborious, c) distraction of crops and farming facilities due to natural calamities like typhoon and drought, d) single cropping rice production because of late maturing variety, e) low production yield which is not comparable to conventional/usual rice crop production, f) farm contamination of organic rice due to nearby conventional rice farmers applying synthetic/toxic chemicals, g) lack of pre and post-harvest facilities of organic rice production, $h$ ) high cost of organic farm inputs, i) lack of capital for organic rice production, $\mathrm{j}$ ) insufficient knowledge in organic farming technology particularly in organic rice production, k) lack of market linkages of the product especially reaching out the market niche, 1) farmers sold their organic palay in ordinary price in the market, $\mathrm{m}$ ) insufficient support of the government for financial, technical and marketing assistance like linking the products to the market niche buyers, n) farmers have poor values that result to low adoption of technologies in organic farming, o) low level of awareness and understanding from among farmers about the RA \# 100068 or it is known as Organic Agriculture Law of the Philippines, p) lack of Installed Control System that monitors the production of organic rice, q) there are many requirements and high cost of product registration which the small producers cannot afford, and r) too rigid requirement of product evaluation and high cost of accreditation/certification as organic rice producer imposed by the accrediting body.

\section{Processors:}

On processors, they had constraints in their operations to the following: a) small volume of production of organic rice in the region which cannot sustain the business operation for whole year round, b) limited quantity and no stable supply of organic palay for continuous milling operation, c) lack of organic rice milling or specialized de-huller machine to produce unpolished organic milled rice, d) high cost of milling machine which most organic producers resort to process their harvest through hand pounding, e) organic rice has short shelf life which cannot stock for long time, f) organic milled rice are sold in ordinary price in the market, g) low supply of organic milled rice, and h) insufficient market linkages of organic milled rice particularly outside the province.

\section{Traders:}

Trading operations of organic products in the region had affected and hampered by the following constrains encountered by the traders like: a) no enough and continuous supply of organic milled rice processors/ farmers, b) organic milled rice has short shelf life which cannot be stored in a longer period of time, c) limited supply of milled rice for trading, d) lack of market linkages for market niche, and e) not prepared to buy by ordinary household consumers.

\section{Consumers:}

The ultimate consumers of the products have bothering on the following: a) they claimed for no assurance of the rice they consumed is organically grown following the protocol in organic farming practices, b) insufficient supply of organic rice which cannot provide supply continuously for their needs in whole year round, c) nowhere they can regularly buy organic rice food in the local market, d) few market outlets of organic rice food restaurant or food chain in the locality, e) organic rice has higher/premium price in the market, and f) unpalatable taste of rice particularly to children and elderly/adult consumers.

\section{CONClusion}

Organic production particularly rice is considered infant stage in Region 02, although it has started long time ago by practicing natural farming but they did not gain a momentum to maintain their numbers instead diminishing overtime due to the influences of modern technology that the emphasis was to apply synthetic based farm inputs (not organic) for mass food production. Most farmers in the islands of Batanes are still practicing natural and organic farming, but in the main land of Cagayan Valley, high land farmers in the mountain hills are believed doing these and few small farmers who were educated on organic farming and monitored by the DA.

The different actors/sectors in the value chain of rice are active especially to the BDS had performed well their tasks to provide supports to the different actors' operations. Their level of performance tasks are varied depending to the locations which attributed to accessibility of resources. Most of farm input suppliers are also producers of organic rice producing farm inputs like organic fertilizers, botanical pesticide/bio-spray and organic seeds for their own use and for market. Even the processors, majority of them are farmer producers of organic rice engaging processing of their own product for their consumption and for market in smaller quantity. Most of them have adopted crude processing of organic rice using hand pounding in de-hulling rice and making native delicacies as their household livelihood. Institutional processors are observed in the urban centers in the different provinces selling organic cook rice served in restaurants, bus station terminals, food chains, caterers and hospitals as one of their amenities. On trading operation is found out that organic rice has mixed with conventional rice 
marketing practices. The marketing and trading of organic rice is not yet well established unlike the conventional rice.

The different actors in the value chain in organic rice have played their roles in the chain like farm inputs suppliers provide farm inputs needed by farmers. The farmer producers are going to provide their produce to the processors/millers, processors/millers then sells their milled rice products to the traders, while traders will supply their products to institutional users and to household consumers. Transient consumers are then supplied by the institutional rice food providers like restaurants, canteens, hotels, hospitals and fast food chains.

The value added mapping of costs of organic rice in different provinces, processors had contributed with the highest cost share of the total consumers price of organic rice $(\mathrm{Php} 140.00 / \mathrm{kg})$ in Batanes with $39.29 \%$. In Isabela, farmer producers and institutional consumers had contributed with the highest cost share to the final price (Php107.40/kg) of upland produced organic rice with $35.44 \%$ and $34.82 \%$, respectively, while institutional consumers and farmers had for lowland produced organic rice with $34.82 \%$ and $34.45 \%$, respectively. Traders had contributed much with $39.81 \%$ for upland produced organic rice, while processors contributed much with $39.81 \%$ for lowland produced organic rice to the total cost structure of Php108.00 per kg in Cagayan province. In Quirino province having with final price of organic rice to Php 120.00 per kg, $29.17 \%$ of this cost is contributed by the traders. Finally, Nueva Vizcaya has final price of Php108.00 for organic red rice and Php96.00 for organic white rice. Institutional consumers had contributed with highest cost share of about $47.92 \%$ for white and $44.44 \%$ for red rice variety. On final price of the product, Batanes organic rice has highest obtained final price per kilogram.

There were various challenges/constraints faced by the different sectors along the chain of organic rice production, processing and marketing in Region 02 that affected to their operations.

\section{RECOMMENDATIONS}

Based from various challenges, problems and constraints faced by all sectors along Value Chain of rice (in transition to organic) in Region 02, the following recommendations are set forward for government's policy options:

\section{A. BDS Providers}

- There should be a need to improve the delivery system of BDS to their clients. Proper programming of their activities and review their priorities suit to the needs of the clients (specifically to each sector in organic rice value chain). Need more competent manpower and logistic supports for better delivery of services reaching to as far as far-flung places in each province in Region 02 .

- Strict implementation of Organic Agriculture Law (RA \# 10068) in the country and other related Laws. Implementing rules and regulations of the program must be reviewed and provide greater participation of those program implementers found at the tip most (e.g. LGUDA) in organizational structure.

- Continuously provide the basic support services that are needed by the client's sectors along the value chain of rice in transition to organic. From among the highlighted support services are technology trainings on organic, financing, and access to product marketing.

\section{B. Farm Input Suppliers}

- They need technical, financial, and marketing supports for their entrepreneurial endeavors. From among other concerned of the farm input suppliers are assistance of identification of organic farm input products, trainings on production, packaging, trade marking, and marketing which includes product promotion and accessing the buyers. Financial support is likewise needed by them to finance the operation and sustenance of the business.

- There must strict implementation of Organic Agriculture Law (RA \# 10068) and other related Laws. Farm input suppliers can be benefited on this by proper implementation of organic programs/protocols that must observed in production, processing and marketing of organic farm inputs.

- They need support to conduct research and development of organic farm inputs. This endeavor will determine the content, level of efficacy of the products e.g. botanical chemicals, and draw for proper recommendations in the use of the product.

- Farm input producers/suppliers' accreditation. They need accreditation of their business name and product for protection of the industry and they can be able to take advantage during marketing.

\section{Farmer Producers}

- There is a need to conduct training on organic farming, processing and marketing of the products. Most claimants of this are farmers found in the far flung areas in the provinces of Region 02. Furthermore, other organic farmer practitioners have not fully understood and internalized the concept of organic farming.

- There should be readily available and enough volume of organic farm inputs in the market like organic rice seeds, organic fertilizers, botanical chemicals (biospray), and other supplies.

- Strict implementation and monitoring of Organic Agriculture Law, and strengthen the implementation and organization of NOAB particularly in municipal and barangay level. People responsible of program implementation must fully aware on it particularly to said organization.

- Organization of organic producers in each province and region. The organization will facilitate their needs for technical, financial and marketing of products. Through this the organization will become responsible to access on it.

- There is a need for organic rice producers' accreditation. The government must provide support on accreditation of farmer producers particularly subsidizing the cost of the registration.

- The government will develop schemes to encourage farmers to engage in organic farming particularly on rice production. Through this will increase the production area of organic rice and increase available supply of products in the market.

\section{Processors}

- Provide technical, financial and marketing supports. They need technical information on proper processing of the 
rice e.g. milling, to solve short shelf life of milled rice, and proper storage. They likewise needed a capital for the operation, acquisition of processing equipment like dehuller machine, and accessing the market of the product.

- Organization of small processors is necessary for institutionalization of support delivery systems.

\section{E. Traders/retailers}

- Help access the market niche of organic rice products not only in the province, region, and country but also in foreign markets.

- There is a need for organic rice organization of traders/retailers in the region for institutionalization of support delivery system from GOs and NGOs. This would be the venue for technical, financial, research and marketing supports for the member traders of the organization.

\section{F. Consumers}

- The government concern agencies like DA, DTI and DOST must conduct continuous education for product utilization or consumption of organic products including the benefits that they can get from it.

\section{APPENDICES}

APPENDIX 1. VALUE ADDED MAP OF RICE (IN TRANSITION TO ORGANIC) FOR UPLAND IN BATANES

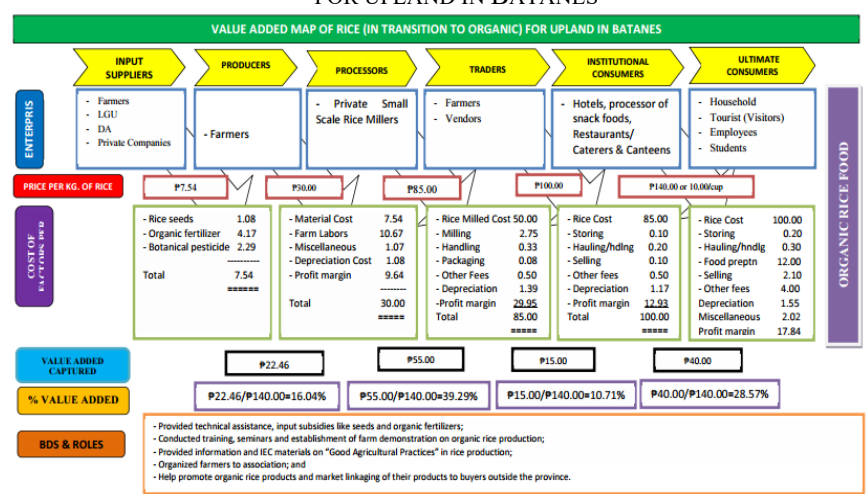

APPENDIX 2. VALUE ADDED MAP OF RICE (IN TRANSITION TO ORGANIC) FOR LOWLAND IN ISABELA

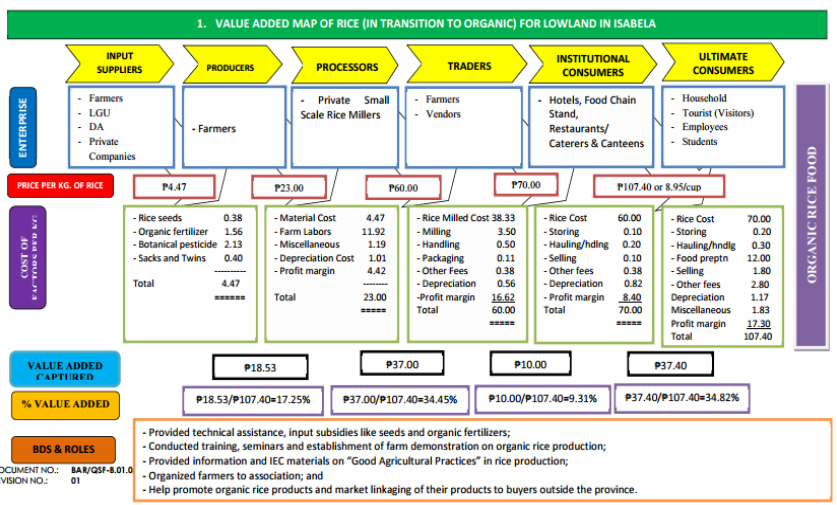

APPENDIX 3. VALUE ADDED MAP OF RICE (IN TRANSITION TO ORGANIC) FOR UPLAND IN ISABELA

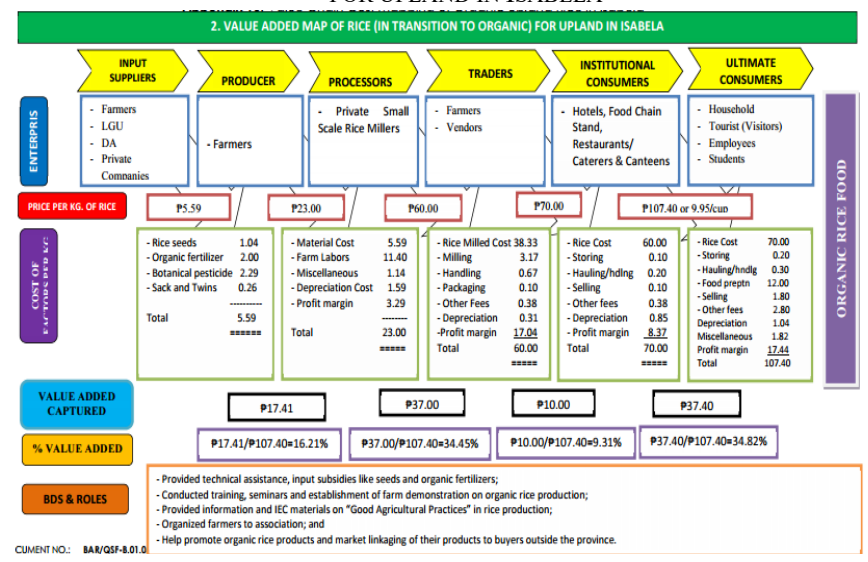

APPENDIX 4. VALUE ADDED MAP OF RICE (IN TRANSITION TO ORGANIC) FOR UPLAND IN CAGAYAN

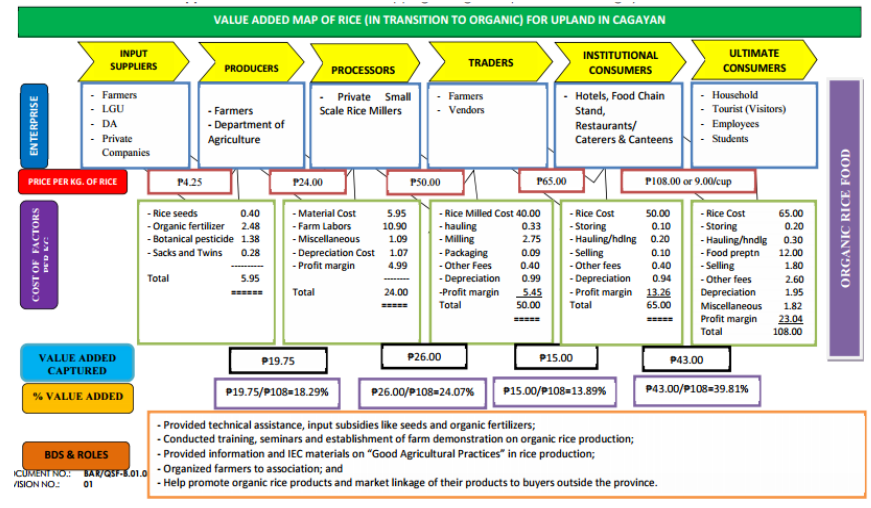

APPENDIX 5. VALUE ADDED MAP OF RICE (IN TRANSITION TO ORGANIC) FOR LOWLAND IN CAGAYAN

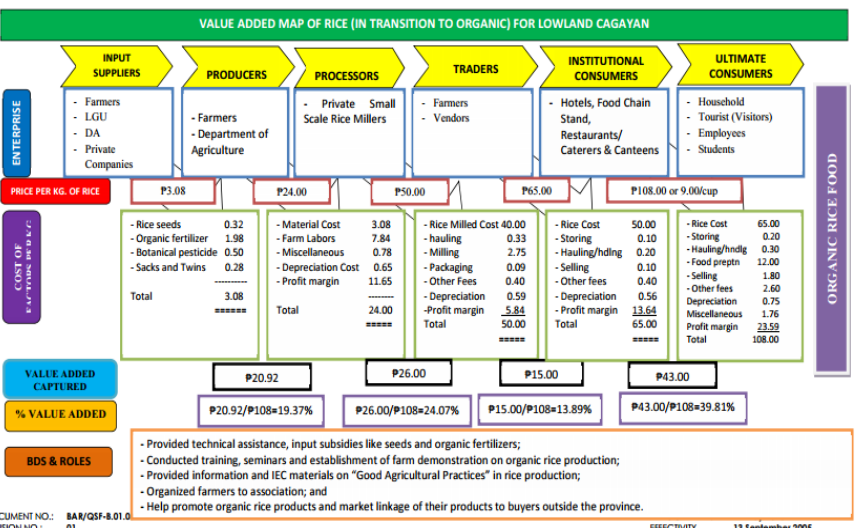

APPENDIX 6. VALUE ADDED MAP OF RICE (IN TRANSITION TO ORGANIC) FOR UPLAND IN QUIRINO

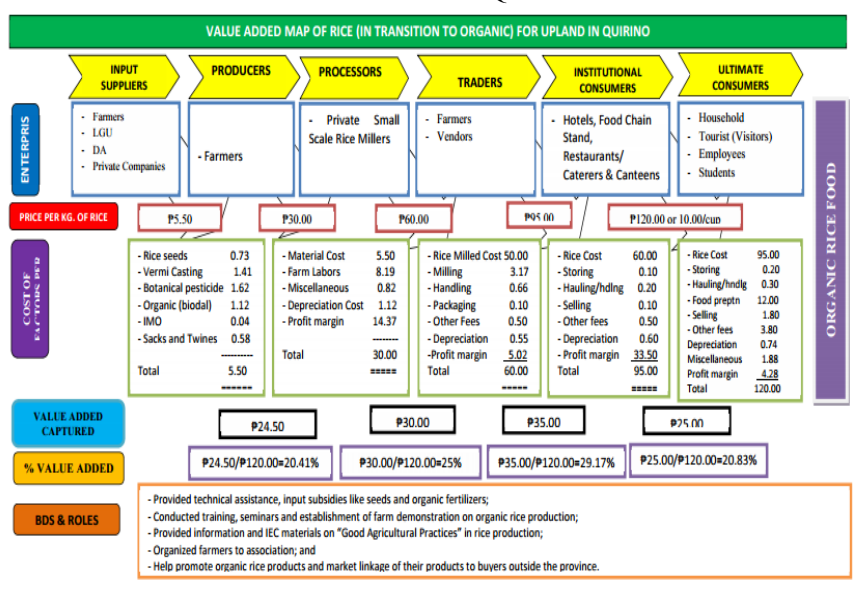


APPENDIX 7. VALUE ADDED MAP OF RICE (IN TRANSITION TO ORGANIC) FOR LOWLAND WHITE VARIETY IN NUEVA VIZCAYA

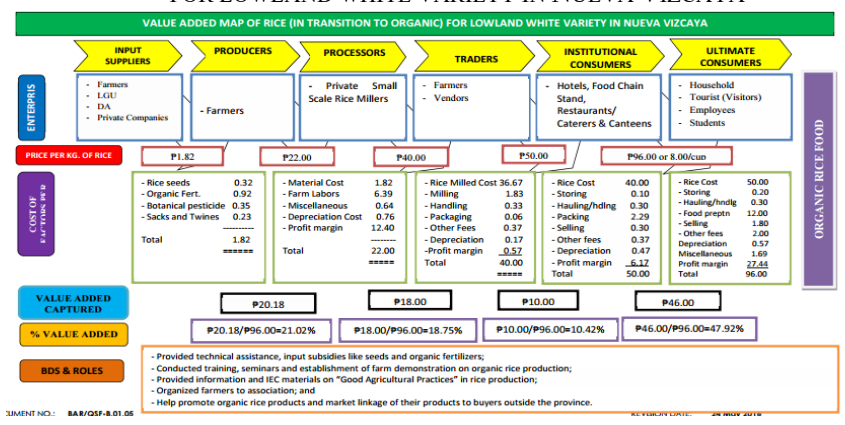

APPENDIX 8. VALUE ADDED MAP OF RICE (IN TRANSITION TO ORGANIC) FOR LOWLAND RED VARIETY IN NUEVA VIZCAYA

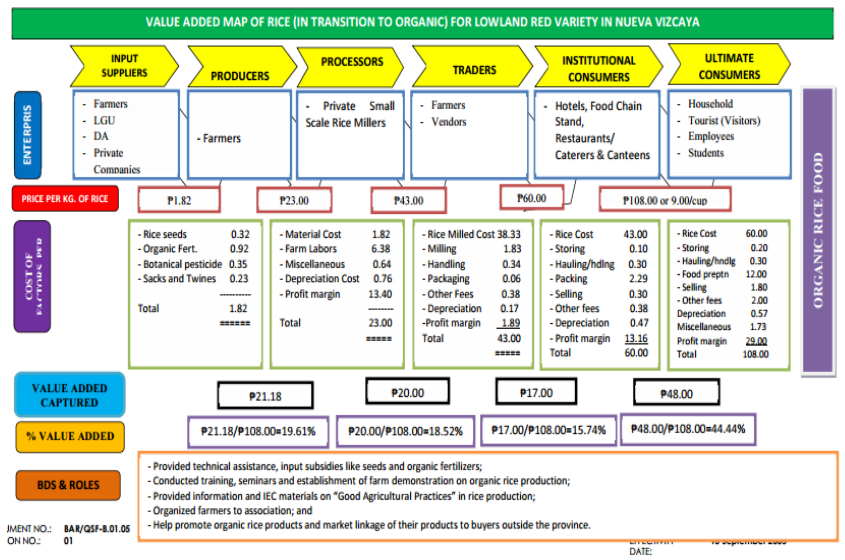

\section{ACKNOWLEDGMENT}

Thanks to the Department of Agriculture - Bureau of Agricultural Research (DA-BAR) for provide funds in conducting this study. Likewise, also to the Isabela State University in letting us to undergo this study.

\section{REFERENCES}

[1] NOAB (2016). The National Organic Program in the Philippines. http://organic.da.gov.ph/ images/docs/National\%20Organic\%20Agriculture\%20Program.pdf

[2] Reinforcing the Role of Cagayan Valley as the Food Basket of the Philippines. http://rdc.rdc2.gov.ph/docs/Reinforcing $\% 20$ the $\% 20$ Role $\% 20$ of $\% 20 \mathrm{C}$ V\%20as\%20the\%20Food\%20Basket\%20of\%20the\%20Phils.pdf

[3] https://goorganicphils.files.wordpress.com.

[4] Pearl2 (2007) "Technical Paper \#1: State of the Sector Report Philippine Organic Products", downloaded from www.philexport.ph, May 5, 2011. $11 \mathrm{P}$

[5] Department of Agriculture (2010). Bulletin of Information, Elliptical Road, Department of Agriculture, Quezon, City. Department of Agriculture. Information Technology Center for Agriculture and Fishery (ITCAF) Enterprise Geospatial Information Systems for Analysis and Learning Laboratory.

[6] PHILDRRA, (2004) Philippine Organic Rice: Industry Orientation paper. Paper presented during the National Forum on Organic Rice Industry, November 18, 2004, Quezon City.

[7] Pabuayon, I.M. and Quilloy, A.J.A. (2011). Brown Rice Market Chain and Marketing Practices, Luzon, Philippines, Department of Agricultural Economics, College of Economics and Management, University of the Philippines Los Baños, College, Laguna, Philippines, Author for correspondence; e-mail address: isabelitampabuayon@yahoo.com; Tel./Fax: 63-049-536-3292, PHILIPP AGRIC SCIENTIST Vol. 94 No. 1, 54-65 March 2011

[8] Philippine Council for Sustainable Development (2004). Revisiting the Philippine Agenda 21. Building a framework plan for long term sustainable development.
[9] Philippine Statistics Authority (2010). The 2010 Census of Population and Housing. https://psa.gov.ph/content/2010-census-population-andhousing.

[10] http://pasmethph.tripod.com/sitebuildercontent/sitebuilderfiles/lecture12.pdf

[11] Dooren, I.C.V. (2005). Rice Value Chain Analysis, "Each life starts with a little seed" For IFAT/EFTA/FLO, $94 \mathrm{Mu} \mathrm{4,} \mathrm{T.} \mathrm{Kummaet,} \mathrm{A.}$ Kutchum, Yasothorn Land 30 rai about 17 rai Hom Mali

[12] Edwardson, W. and Santacoloma, P. (2013). Organic supply chains for small farmer income generation in developing countries Case studies in India, Thailand, Brazil, Hungary and Africa. Agribusiness and Food Industries Series. Food and Agriculture Organization of the United Nations, Rome, 2013. ISBN 978-92-5-107411-4

[13] Cruzada E. (n.d). "Masipag farmers: Beyond putting food on the table", downloaded from www.masipag.org, May 5, 2011.

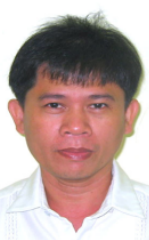

Diosdado C. Cañete was born in Cauayan, Negros Occidental, Philippines on February 20, 1965. He is graduated in his Doctorate Degree in Doctor of Philosophy in Institutional Development and Management at Isabela State University (ISU), Echague, Isabela, Philippines in 2002.

$\mathrm{He}$ is with ISU for 31 years as professor in agribusiness, management and economics courses and handling administrative position in the University. In 1997 to 2003 was assigned as Department chair of the Department of Agribusiness \& Agricultural Economics, 2004 to 2012 was a University Director of Management Information System and 2013 to present was assigned as Chair of the said Department. He published various research output at local research journals accredited by the government, while one article published currently to Asean Academic Associates Publication. He published Migration Pattern of Migrants in Region 02, Income and Income Distribution of Migrants in Region 02, Stochastic Frontier Analysis of Rice Terraces in Mayaoyao, Ifugao, Analysis of Malaya Dairy Cooperative in Mallig, Isabela: A Case Analysis, Factors Influencing Productivity and Technical Efficiency of Rice Farmers Isabela, Philippines, and Marketoriented Agri-Technology and Agri-Extension Services for Agrarian Reform Community Connectivity and Economic Support Services (ARCCESS) for Isabela.

Dr. Cañete a member of various professional organization within and outside the country such as: Federation of Agricultural Economics Development Association, UPLB; Philippine Association of Research Managers (PhilARM). UPLB; International Society for Southeast Asian Agricultural Sciences (ISSAAS); Council of Economic Educators (CECON), UPLB; and Philippine Association of Agriculturists, Inc. (PAA), UPLB. 